\title{
Venous Thrombosis, Oral Contraceptives and High Factor VIII Levels
}

\author{
K. W. M. Bloemenkamp 1, F. M. Helmerhorst 1, F. R. Rosendaal ${ }^{3}$ 3, J. P. Vandenbroucke ${ }^{2}$ \\ From the 'Department of Obstetrics, Gynaecology and Reproductive Medicine, \\ ${ }^{2}$ Department of Clinical Epidemiology, \\ ${ }^{3}$ Thrombosis and Hemostasis Research Center, \\ Leiden University Medical Center, Leiden, The Netherlands
}

\section{Summary}

Recently, it has been described that elevated plasma levels of factor VIII are a strong risk factor for venous thrombosis We analysed the data of the Leiden Thrombophila Study, a population based casecontrol study on the causes of venous thrombosis, to verify whether the risk due to oral contraceptive use was higher in women with higher factor VIII levels Furthermore we investigated the joint risk of high factor VIII levels and oral contraceptive use

We selected 155 premenopausal women with deep-ven thrombosis and 169 control subjects, aged 15-49, who were at the time of then thrombosis (or similar date in control) not pregnant, nor in the puerperium, did not have a lecent miscarriage, and were not using injectable progestogens Of the patients, $109(70 \%)$ women had used oral contraceptives during the month preceding their deep-vein thiombosis, in contrast to $65(38 \%)$ of the control subjects (index date), yielding an odds ratı for oral contraceptive use of 38 (95\% CI 24-60) Of the women who suffered a deep-ven thromboss $56(36 \%)$ had high factor VIII levels ( $\geq 150 \mathrm{IU} / \mathrm{dl}$ ) as compated with $29(17 \%)$ of the control subjects, yielding an odds ratio for high factor VIII of 40 (95\% Cl $20-80)$, relatıve to factor VIII levels $<100 \mathrm{IU} / \mathrm{dl}$ The joint effect of oral contıaceptive use and high factor VIII resulted in an odds ratio of 103 (95\% CI 3 7-28 9), comparing women who had both with women who had neither We conclude that there is an increase in usk due to oral contiaceptive use in women with higher factor VIII levels and that both factors have additive effects

\section{Introduction}

Ot al contraceptive use increases the risk of venous thrombosis, with estımates of the relatıve usk varyıng trom 211 (1) Recently, we described an interaction between oral contraceptive use and carrier-shıp of factor $V$ Leiden mutation, this combination leads to a 30 -fold increase in risk of deep-vein thiombosis (2) This interaction is relevant, since both factor $\mathrm{V}$ Leiden and oral contraceptive use are common

Another common risk factor for venous thrombosis is elevated levels of procodgulant factor VIII (3-5) For men and women in the Leiden Thrombophilid Study, high factor VIII levels ( $\geq 150 \mathrm{IU} / \mathrm{dl}$ vs $<100 \mathrm{IU} /$ dl) had an odds ratio of 62 (95\% Cl 34-11) (3) This effect is not ex-

Contespondence to Piol F R Rosendaal, Department of Clinical Epidemılogy, Leiden Universily Medical Centeı, Bldg 1 CO P, P O Box 9600, 2300 RC Leiden, The Netherlands - Tel +31 71 5264037, FAX Number +31 71 5248122, E-Masl Rosendaal@mal medfac LeidenUniv nl plained by elevated factor VIII levels as a post thrombotic acute phase reaction (4) It is plausible that high levels of factor VIII have a mixed genetic and environmental ongun

We investigated whether the risk due to oral contraceptive use was affected by factor VIII levels

\section{Patients and Methods}

The patients and methods of our study have been described previously $(2,5)$ We invited 474 consecutive patients (both sexcs) with a first eptsode of proven deep ven thrombosis (diagnosed by established objective methods) occurtung between Jan 11988 and Dec 31, 1992 aged less than 70 years and without a known malıgnant disorder Patients had been selected from the $t_{1}$ les of thiee Anticoagulation Clinics in the Netheilands, which monitor anticoagulant treatment in all pattents within a well defined geographical area For each thrombosis patient we invited one age and sex matched healthy control subject For patients we used the date of their dcep-vein thrombosis, for the control subjects we used the date of their corresponding case in the onginal study (ndex datc) Patients were secn only after anticoagulant tieatment was discon tinued for at least three months

For the picsent andlysis we selected only premenopausal women, aged 15-49, who were at the tume of then thrombosis (or similat date in control) nol plegnant, nol in the puerpet uum, did not have a recent miscarriage, and were not using injectable plogestogens

Blood collection Blood was collected into Sarstedt Monovctte ${ }^{\bigcirc}$ tubes, containing $0106 \mathrm{mmol} / \mathrm{l}$ tisodium citrate, and into a Becton Dickinson Vacutanet ${ }^{\mathbb{D}}$ tube fol blood gioup determinations Plasma was prepased by $\mathrm{cen}$ trilugation for $10 \mathrm{~min}$ at $2000 \mathrm{~g}$ at room temperatule and stored at $70^{\circ} \mathrm{C}$

Laboratory measurement Factor VIII coagulant activity (FVIIl C) was measuicd by one stage clotting assays using factor VIII deficicn plasma and automated APTT (Organon Teknıca, Durham, USA) on a Electı a 1000c (MLA, Pleasantville, USA) Pooled normal plasma, standard calıbrated against the WHO standaid tor factor VIII was used as a reference The technicrans did not know if the sample was trom a patient or a contiol or tiom an oral contrd ceptuve user ot non user

Analysts and statistics We analysed data from 155 cases and 169 controls about current use of oral contraceptives at then thrombosis- or index date We stated with univalate analysis by unconditional regression to estimate the odds ratio for respectively oral contiaceptive use and high factor VIII (in diffeicnt strata) or combinations Multivariate analysis by unconditional logistic regiession was used to adjust for possible contounders, $\mathrm{c} g$ age, tamily history of venous thiombosis, history of pregnancy Oral contiaceptive use was entered dichotomously ( 0 tor non oral contraceptive user (curiently) and 1 for curtent oral contraceptive use) Clotting factor VIII was entered dichotomously, 1 tor tactor VIII $\geq 150 \mathrm{IU} / \mathrm{dl}$ and 0 for factor VIII $<150 \mathrm{IU} / \mathrm{dl}$ and also as catcgorized van Iables (strata tactor VIII $<100 \mathrm{IU} / \mathrm{dl}, 100125 \mathrm{IU} / \mathrm{dl}, 125150$ $\mathrm{IU} / \mathrm{dl}$ and $\geq 150 \mathrm{IU} / \mathrm{dl}$ ) 
Table I Venous thrombosis 11sk for categones of lactor VIII

\begin{tabular}{cccccc}
\hline FVIII C strata & IU/dl & Patents & Conitrols & Odds ratıo & $95 \%$ C I \\
\hline$<100$ & 20 & 41 & 1 & & \\
100125 & 40 & 55 & 15 & 0829 \\
125150 & 39 & 44 & 18 & 0936 \\
$>150$ & 56 & 29 & 4 & 20 & 80 \\
\hline
\end{tabular}

Although the original data were age matched we peiformed unmatched analysis Due to the inclusion criteria and age cut ofl many pars wcie no longer intact in the database for this analysis Since the andlysis was restricted to the matching factor sex we ddjusted lor confounding by the other m tching lactor age by controlling for age by logistic iegiession Age was entered into the models as a contunuous variable (in years) after assessing that using a cate gorized dummy variable model led only to tuvial difterences for the cstımators of interest

\section{Results}

We selected from the original study 155 premenopausal women who had had a deep vein thrombosis and 169 control subjects

We used two types of analysis when analysing the factor VIII datd, firstly we analysed simple dichotomy (factor VIII levels $\geq 150 \mathrm{IU} / \mathrm{dl}$ vs

Table 2 Distribution of women with deep ven thromboss and control subjects by oral contraceptive use (OC) and presence of high factor VIII (factor VIII $\geq 150 \mathrm{IU} / \mathrm{dl}$ vs factor VIII $<150 \mathrm{IU} / \mathrm{dI}$

\begin{tabular}{|c|c|c|c|c|c|}
\hline & & Patients & Controls & Odds ratıo & $95 \% \mathrm{Cl}$ \\
\hline$O C()$ & FVIII () & 26 & 89 & 1 & \\
\hline$O C(+)$ & FVIII () & 73 & 51 & 49 & $(28886)$ \\
\hline$O C()$ & FVIII $(+)$ & 20 & 15 & 45 & $(2 \quad 1 \quad 102)$ \\
\hline \multirow[t]{2}{*}{$O C(t)$} & FVIII $(+)$ & 36 & 14 & 88 & $\left(\begin{array}{llll}4 & 1 & 18 & 8\end{array}\right)$ \\
\hline & & 155 & 169 & & \\
\hline
\end{tabular}

Table 3 Distribution of women with decp ven thrombosis and control subjects by oral contraceptive use $(\mathrm{OC})$ and presence of high factor VIII (factor VIII $\geq 150 \mathrm{IU} / \mathrm{dl}$ vs factor VIII $<100 \mathrm{IU} / \mathrm{dI}$ )

\begin{tabular}{|c|c|c|c|c|c|}
\hline & & Patıents & Controls & Odds ratıo & $95 \% \mathrm{Cl}$ \\
\hline $\mathrm{OC}()$ & rVIII () & 7 & 28 & 1 & \\
\hline OC $(+)$ & FVHI () & 13 & 13 & 40 & $\left(\begin{array}{llll}1 & 3 & 12 & 4\end{array}\right)$ \\
\hline OC (1) & FVIII (+) & 20 & 15 & 53 & $(18155)$ \\
\hline \multirow[t]{2}{*}{ OC $(+)$} & FVIII (t) & 36 & 14 & 103 & $(37289)$ \\
\hline & & 155 & 169 & & \\
\hline
\end{tabular}

tactor VIII levels $<150 \mathrm{IU} / \mathrm{dl}$, secondly we stratıfied in four ditterent categories

\section{High Factor VIll}

Dichotomous analysis showed that of the 155 women who suffered a deep-vein thrombosis, $56(36 \%$ ) had high tactor VIII levels (above $150 \mathrm{IU} / \mathrm{dl})$ as compared with $29(17 \%)$ of the 169 control subjects, yielding an odds ratio of 27 (95\% CI 1646 ) Table 1 gives the results for the categonized levels of tactor VIII It shows an increasing risk of venous thrombosis for increasing levels of factor VIII The results tor VIII are most prominent if factor VIII levels are $\geq 150 \mathrm{lU} / \mathrm{dl}$ For levels exceeding $150 \mathrm{IU} / \mathrm{dl}$, the risk was 4 -fold mcieased $(95 \% \mathrm{CI} 2080)$ as compared with women with factor VIII levels $<100 \mathrm{IU} / \mathrm{dl}$

\section{Oral Contraceptive Use}

Of the patients 109 women $(70 \%)$ had used oral contraceptives during the month preceding their deep vein thrombosis in contrast to $65(38 \%)$ of the control subjects yielding an odds tat1o tor oral contraceptıve use of $38(95 \%$ Cl 2460$)$

\section{Oral Contraceptive Use and Factor VIII}

Table 2 shows separate effects and combined effects of factor VIII (factor VIII levels $\geq 150 \mathrm{IU} / \mathrm{dl}$ vs $<150 \mathrm{IU} / \mathrm{dl}$ ) and oral cont aceptıve use As the table shows the separate effects of oral contraceptive use and high factor VIII levels are about the same 49 respectively 45 fold increased risk compared with those with normal factor VIII levels who did not use ordl contraceptives The risk of the combination of oral contraceptive use and high factor VIII, compared with women with low factor VIII who did not use oral contraceptives was 88 fold incieased

This subdivision for oral contraceptive use was also performed for the different strata of factor VIII (100-125 IU/dl, 125-150 IU/dl and $\geq 150 \mathrm{IU} / \mathrm{dl}$ ) in comparison with low levels of factor VIII $(<100 \mathrm{IU} / \mathrm{dl})$ The results of the combined effects of oral contraceptive use and factor VIII (two extreme strata of factor VIII, $\geq 150 \mathrm{IU} / \mathrm{dl}$ compaled with $<100 \mathrm{IU} / \mathrm{dl}$ ) are shown in Table 3 , showing a slightly more pronounced effect of high factor VIII levels

\section{The Logistic Model}

The age-adjusted odds ratto for ord contraceptive use was $55(95 \%$ CI 3 2-9 6) The age adjusted odds ratio for factor VIII differed only slightly from the crude odds ratio, with an odds ratio for those with high factor VIII levels ( $\geq 150 \mathrm{IU} / \mathrm{dl}$ ) and oral contraceptive use of $138 \mathrm{com}-$ pared with those with low levels of VIII $(<100 \mathrm{IU} / \mathrm{dl})$ and not using ord contraceptives (Table 3) Adjustment for family history of venous thrombosis or history of pregnancy did not change the estimators of interest

\section{Incidence of Population}

The combined effects of factor VIII levels and oral contraceptive use can be seen best by back-calculation to the population incidence rates, as shown in Table 4 To show the absolute eftect of the cumulation of risk factors, we estimated the population incidence of thrombosis in young women with the four possible combinations of high tactor VIII levels and use of oral contraceptives We estimated the total number of person years that had ylelded the cases and partitioned these person- 
Table 4 Current use of oral contraceptives (OC) among pattents and contiol subjects according to piesence of high factor VIII ( $\geq 150 \mathrm{IU} / \mathrm{dl}$ )

\begin{tabular}{llll}
\hline & Pattents & Person years* & $\begin{array}{l}\text { Incidence per 10000 } \\
\text { person-years }\end{array}$ \\
\hline Low factor VIII & & & \\
No OC use & 26 & 389704 & 07 \\
Current OC use & 73 & 223313 & 33 \\
High factor VIII & & & 3 \\
No OC use & 20 & 65680 & 59 \\
Current OC use & 36 & 61301 & \\
\hline
\end{tabular}

years according to the distribution of oral contraceptive use and high factor VIII levels in the control group Since we know that in the orig1nal study 117 female patients aged 15-49 came from the Leiden ant1coagulation clinic, which has a geographical source population of 109824 women in that age gioup (data provided by the municipal administration), firstly the thrombosis incidence among young women without underlying disease in the Netherlands can be estimated over the 5 years of our study as 21 in 10000 women-years $(117 /[5 \times 109824])$ Division of the number of women with venous thrombosis by the propot tional number of person years in the categories in oral contraceptive use and high factor VIII levels (propoitions taken from the control group) gives estimates of the population incidences As we know that the population incidence in this age bracket is about $21 / 10000$ py (2), the 155 cases were generated by 740000 women years of follow-up These can be patitioned according to the distribution of the control group which represents this source population (89/51/15/14) Y1elding 389704 women-years for the combination of high factor VIII ( $\geq 150 \mathrm{IU} /$ dl) and oral contraceptive use The incidence of thrombosis increases from 07 per 10000 women per year for non-users of oral contraceptives without high factor VIII to 59 per 10000 for those with high factor VIII who also use oral contraceptives The absolute increase in thrombosis risk due to oral contraceptive use ( 1 e, isk difference) is laiger in women with high factor VIII than in women with low factor VIII $(<150 \mathrm{IU} / \mathrm{dl})$ The joint effect of the two risk factors is additive, in women with low factor VIII there are 26 additiond cases per 10000 women per year when women use oral contuaceptives and in women with high factor VIII (non-users) theie are an additional 23 cases pel 10000 women per year The combination of the two risk factors give an additional of 52 cases per 10000 person-years

\section{Discussion}

We previously reported that the effect of blood group and von Wille brand factor, were both mediated through factor VIII in their effect on venous thrombosis $(3,6)$ In the present study we have investigated the jount effect of factor VIII and ord contraceptive use and found that therr effects are additive

In univariate analysis, high factor VIII and oral contraceptive use were associated with deep-ven thrombosis (Table 1,2 and 3) The odds ratio for oral contraceptive use among low tactor VIII was 40 The odds ratio for factor VIII among non-users was 53 From these odds ratios we can calculate what to expect under different models of interaction Under an ddditive interaction model the total excess risk of oral contraceptive use and factor VIII would be 83 ( 40 plus 53 minus 1 ) Under a multiplicative model, total risk of joint presence of factor VIII and otal contraceptive use would be $40 \times 53=212$ The observed datd dre veiy close to the additive expectation, as we found an odds ratio of 103 Apparently, both oral contraceptive use and high factor VIII increase the risk of venous thrombosis, while the joint presence of both risk factors does not lead to an excess of cases This can also be seen in the population incidences for the varrous risk factors combinations (Table 4)

This is diffeient from the previously reported interaction between factor $V$ Leiden mutation and oral contraceptive use, which interact in a way that exceeded the additive expectation (2)

When adjusting for factor $V$ Leiden in the multivarate model with oral contraceptive use, high factor VIII, age, family history of venous thrombosis and parity (data not shown) the estimators of interest did not change This means that the risk of high factor VIII in combination with oral contraceptive use was not affected by factor $\mathrm{V}$ genotype It can be expected that the more risk factors (genetic or environmental) are piesent, the higher the risk of developing venous thrombosis will be $(7,8)$

Blood group and von Willebrand factor, are both mediated through factor VIII in therr effect on venous thrombosis (3) As we have shown previously, in univariate analysis bloodgroup (non-O), von Willebrand factor levels, and factor VIII levels were all associated with risk of venous thrombosis In multivariate analysis, only an effect of factor VIII levels remained (3) Our tindings are in accordance with data reported in the 1960's, describing that the risk was higher in persons with blood group $\mathrm{A}$ as compared with pessons with blood group $\mathrm{O}$, or more generally "non-O" versus $O(9-12)$, especially during the use of oral contraceptives or during pregnancy or pueiperium $(9,13-16)$ In trying to undeistand the biochemical mechanism behind these clinıcal findings, lower levels of pro-coagulant factor VIII were found in nor mal individuals with blood group $O$ as compared with persons with blood group non-O $(17,18)$ Subsequent research has shown that ind viduals with non-O blood group have higher levels of von Willebrand factor Von Willebiand factor serves as the carrier proton of factor VIII, and so there is a strong correlation between von Willebrand factor levels and factor VIII levels This led to our conclusion that factor VIII levels were the final effector of risk It is unclear, however, by which mechanısm this occurs, although in analogy to other clottıng abnorma littes with a gain of function, e $g$ factor $V$ Leiden, increased thrombin actıvation seems likely The oitgin of high factor VIII levels is not entirely elucidated There exists additional familial clustery beyond the etfects of blood gioup and von Willebiand factor, suggesting additional genetic determınants (6) In addition, acquired deteımınants are likely to play a role, too $(3,4)$, whether oral contraceptives increase factor VIII levels is contioversial (19-24)

In the present study we actually did an analyses of high factor VIII levels, bloodgroup, or al contraceptive use and venous thrombosis, but especially among users the data were to scarce to draw conclusions (data not shown) Neveltheless, we found the expected relationship between high factor VIII and bloodgroup non-O in explaining venous thrombosis during oral contraceptive use, 1 e the known effect of blood gioup on venous thrombosis, could in our data almost entirely be explanned by high factor VIII among non users This is in line with the old observation that there is a deficit of patients with blood group $\mathrm{O}$ in subgroups of young women who develop venous thromboembolism during the use of oral contraceptives (9)

We can conclude that there is an increase in risk due to oral contraceptive use in women with higher factor VIII levels and that both factors have ddditıve effects 


\section{Acknowledgements}

We thank all the patients who took part in this study, Di T Koster, the investigator of the oniginal study, Dr F J M van des Meer (Anticoagulation Clinic Lciden), Di L P Colly (Anticoagulation Clinıc Amslerdam) and Di P H Tilenekens (Anticodgulation Clinic Rotteidam) for theis cooperation, Mis A Schreijer for secietarial and administiative support, Mis T Vissel for laboratory assistance The original study was funded by the Nethel lands Heart Foundation (number 89 063)

\section{References}

1 Bloemenkamp KWM, Rosendaal FR, Helmeıholst FM, Vandenbroucke JP Evidence that currently avaldable pills are astociated with cardiovascular disease venous disease, In Hannatord PC, Webb AMC Evidence-guided Piescubing of the Pill Carnforth UK Pathenon Publishing 1996,61 76

2 Vandenbioucke JP, Kosteı T, Bıtet E, Reıtsma PH, Bcrtınd RM, Rosendaal FR Inueased isk of venous thrombosis in oral-contraceptive users who are carıers of tacto V Leiden mutation Lancet 1994, 344 1453-7

3 Koster T, Blann AD, Briet E, Vandenbroucke JP, Rosendaal FR Role of clotting tactor VIII in effect of von Willebrand factor on occurrence of deep-ven thrombosis Lancet 1995, 345 152-5

4 O Donncll J, Tuddenham EG, Manning R, et al High prevalence of elevdied factor VIII levels in patients teferred for thrombophilia scicening role of increased synthesis and relationship to the acute phase seaction Thromb Haemost 1997, 77 825-8

5 Koste1 T, Rosendaal FR, Ronde H de, Biret E, Vandenbroucke JP, Bertınd RM Venous thrombosis due to poor anticoagulant response to dctivated pıoten C Leıden Thrombophilia Study Lancet 1993, 34215036

6 Kamphuisen PW, Houwing Duıstermadt JJ, van Houwelıngen HC, Eıkenboom JC, Beıtuna RM, Rosendaal FR Familial clusten ing of factor VIII and von Willebrand factor levels Thromb Hacmost 1998, 793237

7 Rosendaal FR Risk factors for venous thrombosis prevalence, risk, and interaction Seminars in Hemalology 1997, 34 171-87

8 Rosendaal FR Thiombosis in the young epidemılogy and risk factors A focus on venous thrombosis Thromb Haemost 1997, 78 1-6

9 Jick H, Slone D, Westerholm B, Inman WHW, Vessey MP, Shapiro $S$, Lew1s GP, Worcester J Venous thromboembolic disease and ABO blood type A cooperative study Lancet 1969, 1 539-42
10 Talbot S, Wakley EJ, Ryrie D, Langman MJ ABO blood-gıoups and venous thiombocmbolic discase Lancet 1970112579

11 Bates $\mathrm{M}$ Venous thromboembolic disease and $\mathrm{ABO}$ blood type Lancet 1971,1239

12 Talbot S, Waklcy EJ, Langman MJ A19 A29 B, and O blood-gioup Lewis blood gioups, and serum triglyceride and cholesterol concentrations in patients with venous thromboembolic disedse Lane 1972111524

13 Hill H, Loudon NB, Pitchet CS, Pocock VM Venous thromboembolic discase and ABO blood type Lancet 1969, I 623

14 Mourant AE, Kopce AC, Domaniewrka-Sobcrak K Blood-groups and blood-clotting Lancet 1971, 1 223-7

15 Westerholm B, Wiechel B, Eklund G Oral contraceptives, venous thrombocmbolic diseasc, and ABO blood type Lancet 1971, Sept 18664

16 Allan TM ABO blood groups and venous thiombocmbolism Lancet 1971 2 1209-10

17 Pieston AE, Barr A Bı J Hacmatol 1964, 10238

18 Wahlbesg TB, Blomback M, Magnusson D Influence of sex, blood group, secretor character, smoking habis, acetylsalicylic acid, ol al contuaceptives, lastung and generdl health statc on blood codgulation var ables in tandomly selected young adults Hacmostasis 1984, 14 312-9

19 Balleısen L, Batley J, Eppıng PH, Schulte H, van de Loo Epıdemıological study on factor VII, factor VIII and libunogen in an industual population I Baseline datd on the relation to agc, gender, body weight, smoking, alcohol, plll-using, and menopause Thromb Haemost 1985, 54 475-9

20 Daume $\mathrm{E}$ Influence of modern low-dose oral contraceptives on hemostass Adv Contraccption 1990, 6 (Suppl) 51-68

21 Robinson GE Low dose combined oral contraceptives Brtush J Obstel Gyndecol 1994, 101 1036-42

22 Fotherby K, Caldwell ADS New progestogens in ord contuaception Contraception 1994, 49 I 32

23 Winkles UH Eftects on hemostatic variables of desogcstrel- and gcstodenc-contaning old contraceptives in comparison with levono1gestrel containing oral contraccptives, a review Am J Obstet Gynccology $1998,179551-61$

24 Klutt C, Lansink M Effect of old contaaceptives on hacmostasis variables Thromb Haemost 1997, 78 315-26

Recelved November 6, 1998 Accepted after revisıon April 14, 1999 